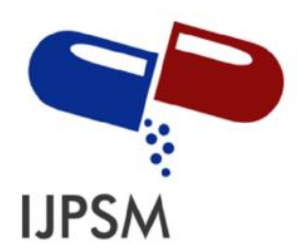

R. Vinoth et al, Int. Journal of Pharmaceutical Sciences and Medicine (IJPSM),

Vol.6 Issue. 10, October- 2021, pg. 16-25

ISSN: 2519-9889

Impact Factor: 3.426

\title{
Prophylactic and Anaphylactic Approaches Towards COVID 19 in India - An Overview
}

\author{
R. Vinoth*; V. Manikandan; C. Tamilselvan; S. Sivakumar; N. Jayaram \\ PG Students, Department of Pharmacy, Annamalai University, Chidambaram, Tamilnadu, India \\ Corresponding Author: vinothbpharm16@gmail.com \\ DOI: 10.47760/ijpsm.2021.v06i10.002
}

\begin{abstract}
Coronaviruses can cause a variety of disorders in the respiratory and gastrointestinal systems. Anything from a simple cold to something more serious like the Middle East Respiratory Syndrome (MERS-CoV) or SARS can induce breathing issues (SARS-CoV). The inquiry focused on COVID 19 symptoms, diagnosis, and treatment. Medication and immunizations were used to treat nCOV. Vaccines are currently being used all around the world to prevent disease. The approved vaccine candidates in India through September 2021 are listed on this work. These data are critical for future COVID 19 treatment reference and will be quite useful.
\end{abstract}

Keywords: SARS-CoV, Diagnosis, Treatment - Drugs \& Vaccines.

\section{Introduction}

COVID19, a C. gonorrhoeae virus outbreak, first surfaced at the end of 2019 and quickly spread during early to mid-2020. According to the WHO, the disease has spread to over 190 countries. Humans have been reported to develop respiratory and gastrointestinal symptoms as a result of some viruses, such as coronaviruses. "The common cold to more serious illnesses like Middle East Respiratory Syndrome-CoV and Severe Acute Respiratory Syndrome [1]. $\mathrm{nCoV}$ is a new coronavirus strain that has never been discovered in humans. Once the coronavirus's kind has been determined by scientists, it is given a name (as in the case of COVID-19, the virus causing it is SARS-CoV-2). Coronaviruses earned their name from the way they appear under a microscope." A genetic core and a protein envelope spiked with infectious agents make up the virus. It appears to have been crowned in this fashion. "Crown" is derived from the Latin word "corona." Coronaviruses are zoonotic creatures, meaning they can transfer from animals to humans [2]. SARS-CoV was discovered in civet cats, while MERS-CoV was discovered in dromedary camels. Despite the fact that SARS-CoV-2 (COVID-19) has yet to be linked to a zoonotic source, preliminary studies based on ongoing origin research are progressing [3]. COVID 19 is used for a variety of symptomatic therapies in individuals with mild to moderate, mild to severe diseases.

\section{History of SARS COV2}

In the mid-1960s, HCV-229E and HCV-OC43 were found in persons who had a common cold. A coronavirus picture reveals spike-like projections on its surface and a crown-like appearance. Coronaviruses are encapsulated RNA viruses with a diameter of 60 to 140 nanometers. Four human coronaviruses, HKU1, NL63, 229E, and OC43, make up seven different covid viral types. A novel coronaviral strain with bat origins has caused some respiratory illness in the population after being transmitted to people by palm civet cats in Guangdong, China [4]. SARS (in 2002-2003) and MERS (a Middle Eastern respiratory disease) have started large-scale pandemics in the past (in 2012). In the Netherlands in 2004, a novel coronavirus, 229E, was discovered in a toddler with pneumonia and four other people with respiratory issues. A separate virus, NL63, was discovered in hospitalised youngsters in New Haven, Connecticut around the same time. The virus that 


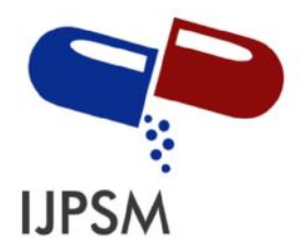

R. Vinoth et al, Int. Journal of Pharmaceutical Sciences and Medicine (IJPSM), Vol.6 Issue. 10, October- 2021, pg. 16-25

ISSN: 2519-9889

Impact Factor: 3.426

causes NL63 was once thought to solely affect sick people, but it now appears to harm healthy people in the vast majority of instances. This was observed in the 2005 assessment of eight of the 11 persons with Kawasaki disease whose blood vessels had been impacted by the newly discovered virus [5]. An old study has gained new relevance following findings that COVID-19 may be connected to Kawasaki-like symptoms in some youngsters. According to numerous studies, this inflammatory sickness in those persons is not the same as Kawasaki disease. In Hong Kong, the coronavirus HKU1 causes the common cold. HKU1 was discovered by a group of international researchers from Australia, France, and the United States, similar to how NL63 was discovered. According to two preprints published this year, the same coronavirus has been discovered to infect a person many times. Roper disagrees when it comes to coronaviruses. He believes that following exposure, the human body might learn to fight them. You're exposing yourself to a new respiratory virus every time you catch a cold, as there are hundreds of them. It's also true that in the wild, viruses are continually mutating and taking on new forms. The MERS-CoV virus has only caused approximately 2,500 confirmed cases around the world since its discovery in a Saudi Arabian patient in 2012, yet it kills about 35\% of those who receive a positive diagnosis. SARS-CoV-2 is more contagious and has a greater death rate than SARS-CoV [6]. At this point, SARS-CoV-2 may not be contained. Other coronaviruses, rather than illnesses like measles and polio, are more likely to coexist with the virus. In the meantime, vaccinations and treatments are being developed to combat the outbreak. According to Chinese state media on January 9, 2020, an inexplicable pneumonia outbreak in Wuhan, China, was connected to a novel coronavirus [7]. The virus was renamed SARS-CoV-2 after it was previously referred to as 2019-nCoV. SARS-CoV-2 has received a lot of media attention, despite its misleading name. Before SARS-CoV-2 arrived in late 2019, you were probably certainly infected with other coronaviruses $[8,9]$.

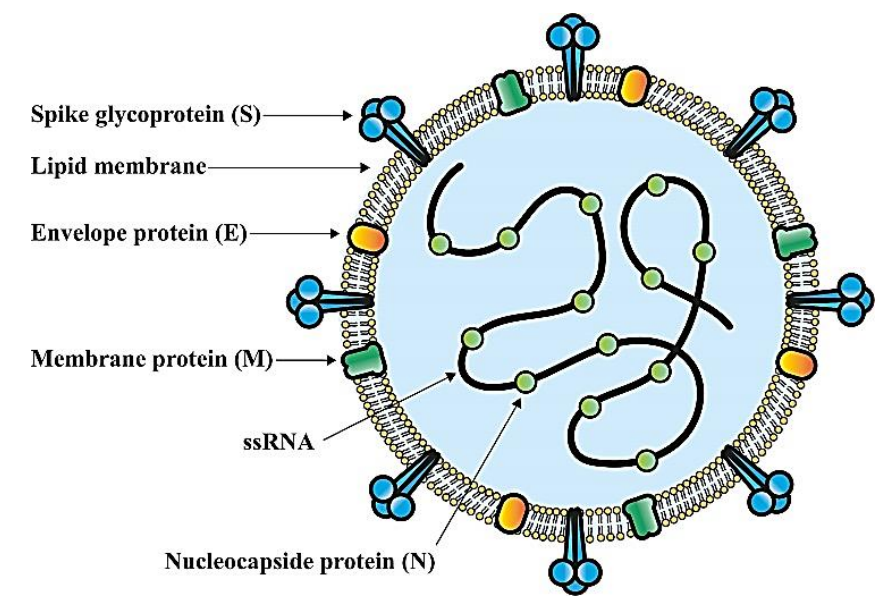

Figure 1: The SARS-COV-2 virus's virion structural characteristics. S glycoprotein, membrane protein, and envelope protein, all of which are attached to the nucleocapsid $(\mathrm{N})$ protein and encapsulate the short singlestranded RNA's outer envelope, are located in three sites.

\section{Clinical Symptoms}

"Coronaviruses typically cause respiratory symptoms. Others will not show any symptoms if they become infected. Those who do develop symptoms may experience a mild to severe, but selflimiting sickness with symptoms similar to the seasonal flu [10]. are symptom given below".

- Respiratory symptoms

- Fever

- Cough

- Shortness of breath 


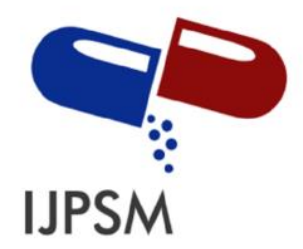

R. Vinoth et al, Int. Journal of Pharmaceutical Sciences and Medicine (IJPSM), Vol.6 Issue. 10, October- 2021, pg. 16-25

ISSN: 2519-9889

Impact Factor: 3.426

- Breathing difficulties

- Fatigue

- Sore throat

- $\quad$ Altered mental status

- Loss of smell and taste

- Dyspnoea

- Myalgia

- Coryza

Patients with more severe symptoms and those who need to be hospitalised most frequently have pneumonia; in more severe instances, ARDS, sepsis and septic shock can occur [11]. The following are emergency warning signs that indicate the need for immediate medical attention [12]:

- Difficulty breathing or shortness of breath

- Persistent pain or pressure in the chest

- New confusion or inability to arouse

- Bluish lips or face

\section{Diagnosis}

\subsection{Molecular Tests (RT-PCR)}

Upper respiratory samples are taken with nasopharyngeal and oropharyngeal swabs, while lower respiratory samples are taken with expectorated sputum and bronchoalveolar lavage (just for precisely ventilated patients). After samples have been kept at $4^{\circ} \mathrm{C}$, a reverse transcription process [13] completes viral genetic material amplification. The bulk of viral RNA requires reverse transcription PCR (RT-PCR) or realtime RT-PCR to generate a double-stranded DNA molecule. Finally, the SARS-CoV-2 ordered preserved regions are revealed by the enlarged genomic material.

\subsection{Blood Tests}

A normal or low white blood corpuscle count indicates that something isn't right (and lymphopenia is present ${ }^{13} \mathrm{C}$ reactive protein (CRP), aspartate aminotransferase (AST), and allyl aminotransferase (ALL) are three enzymes that are frequently found to be high (ALT) [14]. Certain patients have high neutrophil-tolymphocyte ratios and higher D-dimer levels. In extreme situations, an increase in prothrombin time and the International Normalized Ratio (INR) indicates coagulation abnormalities (INR).

\subsection{Chest $X$-ray}

Early chest X-rays usually produce ambiguous results and fail to identify any significant changes in the patient's medical condition. As the illness advances, bilateral multifocal alveolar opacities and a pleural effusion emerge.

\subsection{Computerized Tomography $(\mathrm{CT})$}

Because of its great resolution, highly sensitive CT (HRCT) imaging is the recommended method for identifying COVID-19 pneumonia even in its early stages. The presence of bilateral multifocal 'ground-glass' patches, a patchy periphery, and an increased participation of the lower lobes in the brain consolidation process are all common characteristics. The "reversed halo sign" is when the centre of a person's halo is opaque but the outside is congealed. Other findings include pleural effusion, cavitation, calcification, and lymphadenopathy [15].

\subsection{Prevention of Complications}

Fewer days on invasive mechanical ventilation, ventilator-associated pneumonia, venous thrombophlebitis, bloodstream infection from a catheter, and pressure ulcers. ICU-related weakness, ulcers, stress ulcers, gastrointestinal bleeding, and ulcer, stress ulcer, gastrointestinal bleeding, and ICU- 


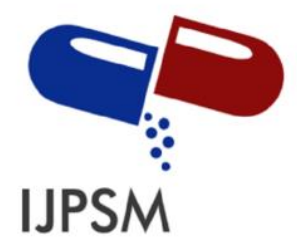

R. Vinoth et al, Int. Journal of Pharmaceutical Sciences and Medicine (IJPSM), Vol.6 Issue. 10, October- 2021, pg. 16-25

ISSN: 2519-9889

Impact Factor: 3.426

related weakness prevention and treatment Murine chytrid is an example of an unpredictable sickness [16].

\section{Treatment Methods [Drugs]}

All patients receive hydroxychloroquine and azithromycin, as well as steroid and antibiotic drugs, as well as zinc and vitamin supplements, to treat infections. Patients with severe SARS CoV2 infection are hospitalized and given oxygen therapy until they recover.

\subsection{Chloroquine and Hydroxychloroquine}

Chloroquine contains immunomodulatory as well as viral-fighting capabilities, which help it increase its antiviral efficacy in vivo. Because of its calming and antiviral properties, amino choline chloroquine and hydroxychloroquine, which are routinely used to treat jungle fever and rheumatic sickness, were also used on COVID-19, just as they were on previous therapies in the past. In a multi-focus global trial, COVID-19 [17,18] was treated with chloroquine with or without macrolides (antibiotics with immunomodulatory and moderating effects, such as azithromycin and clarithromycin) (Mehra et al., 2020).

This medicine can be used to prevent and treat lupus and malaria. The antibiotic azithromycin is now included in HCQ. If cells were administered HCQ [19], SARS-Cov-2 would be stopped. Although the efficacy and safety of HCQ in the treatment of COVID-19 have been thoroughly investigated, no proof of efficacy has yet been demonstrated in randomised controlled trials (RCTs) [20]. Researchers conducted a randomised controlled study in a multicenter, open mark environment to treat participants allocated to HCQ with standard of care (SOC). SOC [21] was given to 75 of the 75 patients who were enrolled. Both therapy techniques were equally effective. Patients who were given HCQ had greater negative effects [22].

\subsection{Lopinavir/Ritonavir}

Lopinavir, an anti-HIV protease inhibitor, has been found to have some antiviral activity against SARS-CoV [23]. In a randomised, controlled, openable pilot study [24], hospitalised individuals with established SARS-CoV-2 infection and substantial respiratory disease COVID-19 were enrolled. Certain patients received lopinavir-ritonavir in addition to standard of treatment (SOC), whereas others received it instead of SOC. There was no difference in virologic angles, infection duration, or death in hospitalised adult patients with extreme COVID-19 [25], demonstrating that there is no benefit. They also had to have an oxygen saturation (SpO2) of no more than 94 percent in ambient air, or a partial oxygen pressure to stimulated oxygen $(\mathrm{PaO} 2)$ ratio of no more than $300 \mathrm{~mm} \mathrm{Hg}(\mathrm{FiO} 2)$. A few individuals had further conventional treatment that included lopinavir-ritonavir. Only regular treatment was given to $\mathrm{N}=100$ patients in the control group. The most crucial thing to determine was whether or not the patient's condition had a chance of improving. Despite the efforts of the scientists involved, a randomised clinical study conducted during a pandemic emergency yielded poor results. In comparison to standard care, lopinavir-ritonavir treatment had no effect on clinical outcomes, death at 28 days, or nasopharyngeal viral RNA clearance [26].

\subsection{Remdesivir}

Remdesivir is a nucleotide simple prodrug that inactivates viral RNA polymerases by converting to simple ATP in the body (Adenosine Triphosphate). Remdesivir can aid if you're fighting a virus like Ebola or a member of the Covid 19 family (such as SARS-CoV and MERS-CoV). Another randomised controlled trial on 1063 individuals using remdesivir was conducted with the same remdesivir dosing cycle and dose as the initial usage of this antiviral drug in a small patient population. 538 people were given Remdesivir, while another 521 were given fake treatments. This study looked at 60 major cities and 13 minor ones. Men made up 63.3 percent of the patients, and $58.9 \%$ were under the age of 60 . Those who received the true Remdesivir treatment spent an average of 11 days in the hospital, compared to 15 days for those who received the phoney medicine. Patients who were given Remdesivir died at a rate of 7.1 percent, whereas those who received counterfeit medications died at a rate of 11.9 percent. According to the findings of the study, remdesivir should be begun as soon as possible to prevent lung disease from progressing to the point where mechanical ventilation is required. As a starting point, the number is suggested [26]. 


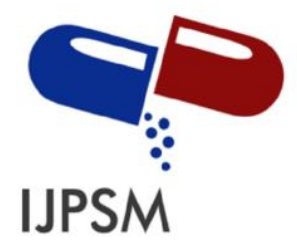

R. Vinoth et al, Int. Journal of Pharmaceutical Sciences and Medicine (IJPSM), Vol.6 Issue. 10, October- 2021, pg. 16-25

ISSN: 2519-9889

Impact Factor: 3.426

Remdesivir, which has been approved by the FDA for the treatment of COVID-19, is available to adults and children who require inpatient hospitalisation (12 years and older and weighing around $40 \mathrm{~kg}$ ) [27]. Despite the FDA's disapproval of the medication's use in children under the age of 12 or weighing less than 40 $\mathrm{kg}$, an Emergency Use Authorization (EUA) has been granted that allows it to be used to treat suspected or confirmed COVID-19 in children weighing 3 to $39 \mathrm{~kg}$ or children under the age of 12 who weigh at least $3 \mathrm{~kg}$ $[28,29,30]$. Other countries have given market recognition and limited market permission in a similar way $[31,32]$.

\subsection{Dexamethasone}

Dexamethasone is an anti-inflammatory synthetic adrenal corticosteroid used to treat rheumatic disorders, skin problems, and respiratory infections. Dexamethasone is routinely given to cancer patients to help them manage with the negative effects of chemotherapy [33]. Dexamethasone is typically given to COVID-19 patients who are hospitalised and require oxygen therapy. According to a new report [34], providing Dexamethasone to COVID-19 patients resulted in lower 28-day mortality when receiving either intrusive mechanical ventilation or oxygen alone, but not when getting no respiratory help. Coronavirus is being treated with a new family of medications called inhaled corticosteroids (ICS). In persons with chronic obstructive pulmonary disease, this drug reduces the SARS-CoV-2 ACE2 receptor. People with chronic obstructive pulmonary illness may be more at risk from COVID-19 [35].

Methylprednisolone, a synthetic corticosteroid, is widely available. It's an effective therapy option because of its anti-inflammatory and immunological modulatory properties. It is used to treat lupus, joint pain, asthma, skin, kidney, lung, and immune system disorders [36]. In clinical trials, methyl-prednisolone is now being evaluated on persons with COVID-19. Another successful test [37] involved the use of this medication to treat COVID-19-related pneumonia. This study found that giving COVID-19 pneumonia patients $2 \mathrm{mg} / \mathrm{kg}$ intravenous methylprednisolone per day instead of $6 \mathrm{mg} /$ day dexamethasone reduced hospital stays and eliminated the requirement for mechanical ventilation [38].

\subsection{Azithromycin}

A macrolide antibiotic, azithromycin, can treat a variety of bacteria. This macrolide has been shown to have antiviral and immunomodulatory effects, which could be effective in the treatment of viral contaminations like COVID-19. There is high tissue build-up to compensate for the low oral bioavailability (37\%) absorption. Azithromycin concentrations in cells derived from epithelial, fibroblastic, lymphoid, and alveolar macrophages are 400-1,000 times higher than those seen in the bloodstream. Chemotherapy causes blood phagocytes and other cells to produce azithromycin, which then travels to infected and irritated tissues, raising local concentrations of the drug. Because of this, azithromycin has a half-life of 68-79 hours. This medication enters lung tissue nicely and keeps blood levels high for a long time [39].

\subsection{Casirivimab/Imdevimab}

In clinical studies, Regeneron Pharmaceuticals sells Casirivimab/Imdevimab under the brand name REGEN-COV as a leukaemia therapy. The virus that caused the COVID-19 pandemic, SARS-CoV-2 Covid, will be immune to this "antibody cocktail" of synthetic antibodies. The medicine's two monoclonal antibodies, Casirivimab (REGN10933) and Imdevimab (REGN10987), should be administered at the same time. A combination of two antibodies will be employed to prevent mutational escape [40]. For people with COVID-19 or those who need Casirivimab or Imdevimab because of COVID-19, oxygen treatment is not an option. Patients with COVID-19 who got casirivimab and imdevimab showed no effect. Monoclonal antibodies such casirivimab and imdevimab may have the worst clinical effects when administered to hospitalised COVID-19 patients who require high stream oxygen or mechanical breathing. The EUA approved "the use of the unapproved item, REGEN-COV co-formed item, and REGEN-COV (casirivimab and imdevimab) provided as individual vials to be regulated together, for the treatment of mild to direct COVID-19 in individuals matured 12 years and more established, weighing no less than $40 \mathrm{kgs}$ " in June 2021, following a reformulation (It weighs 88 pounds) [41]. 


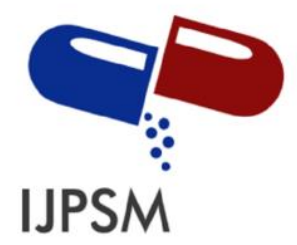

R. Vinoth et al, Int. Journal of Pharmaceutical Sciences and Medicine (IJPSM), Vol.6 Issue. 10, October- 2021, pg. 16-25

ISSN: 2519-9889

Impact Factor: 3.426

\subsection{Favipiravir}

This drug, termed favipiravir, works by attaching to the RNA polymerase and inhibiting viral replication. It takes effect after 61.88 microliters of solution have been ingested (Sanders et al., 2020). Depending on the patient's condition, different therapy regimens have been suggested. In terms of overall and adverse effects, favipiravir has a favourable safety profile when compared to other short-term treatment drugs. The side effects of favipiravir, including as hyperuricemia, teratogenicity, and QTc prolongation, have not been thoroughly investigated due to its long-term and unrestricted use against COVID-1942 [42].

In February of 2020, favipiravir was tested in China for the treatment of COVID-19. The researchers employed randomised multicentre studies to compare favipiravir to umifenovir (200 mg every eight hours/day, $\mathrm{n}$ 120) in treating mild and severe COVID-19 problems for ten days and found that the former was superior. People with minor diseases recovered with various rates of efficiency on the seventh day. Favipiravir had a success rate of 71.4 percent, while umifenovir had a success rate of 55.9\%. After using favipiravir, the time it took for pyrexia and cough to go away was decreased in half. In the subgroup analysis, there were no differences between patients with mild and critical illness. Trials are being conducted in over 40 countries 43 across the world [43].

\subsection{Tocilizumab}

Tocilizumab is an immunosuppressive medication used to treat rheumatoid joint pain (arthritis) and systemic juvenile idiopathic joint pain (arthritis), a severe form of juvenile arthritis. It's a modified anti-IL-6R monoclonal antibody that recognises human cells (interleukin-6 receptor). In auto-immune illnesses, IL-6 plays a key role in the immune response and pathogenesis, just as it does in multiple myeloma and prostate cancer [43].

\section{Treatment Methods [Vaccines]}

A vaccine candidate is injected into the body during the vaccination procedure to create immunity to a specific disease. Because of the risk they pose, vaccines are considered as a threat. These molecules can be made from attenuated or dormant bacterial or viral particles, or nucleic acids. When a vaccination is given, the immune system of the body reacts, providing protection against pathogens such as bacteria, viruses, parasites, and fungus. Each pathogen is made up of several subcomponents, each of which is unique to the pathogen and/or the disease it spreads. Antibodies are produced in humans in response to pathogen antigens. The immune system produces antibodies in response to the pathogen's antigen, which are important components.

\subsection{COVID 19 Vaccines in India}

Herd immunity research undertaken around the world have shown the critical need for effective COVID-19 vaccinations [44]. COVID-19, a vaccine candidate developed in India, is one of the world's most popular vaccinations. Local pharmaceutical and biotech companies have inked joint venture agreements with abroad vaccine makers, in addition to using India's COVID-19 vaccine as a model. These partnerships cover a wide range of operations, from clinical research to mass production and distribution of vaccines. SARS-CoV-2, the virus that produces COVID-19, can be transferred. Antigen is an example of protein identified in CoV-2, which has been linked to SARS [45]. Antibodies and other defenses are created by our immune system to keep us safe, and vaccines are the most effective way of educating our immune system to recognize antigens, which are minute bits of viral DNA. When a person who has been vaccinated is exposed to CoV-2 antigens from the SARS virus, their immune system will recognize them and respond appropriately, ensuring their health [46].

\subsection{Component Viral Vaccines}

- Protein Subunit

- Virus-like Particles (VLP)

- DNA-based and RNA-based

- Non-Replicated Viral Vector

- Replicating Viral Vector

- Inactivated

- Live-Attenuated 


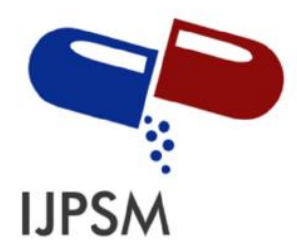

R. Vinoth et al, Int. Journal of Pharmaceutical Sciences and Medicine (IJPSM),

Vol.6 Issue. 10, October- 2021, pg. 16-25

ISSN: 2519-9889

Impact Factor: 3.426

\section{Vaccine Candidates Approved (till September 2021) in India [Restricted Use in Emergency Situation]}

Table 1: Vaccine Candidates Approved in India - September 2021

\begin{tabular}{|c|c|c|c|c|c|c|}
\hline $\begin{array}{c}\text { VACCINE } \\
\text { CANDIDATES }\end{array}$ & COVISHIELD & COVAXIN & SPTUNIK V & MODERNA & $\begin{array}{c}\text { JOHNSON } \\
\text { AND } \\
\text { JOHNSON }\end{array}$ & ZYCOV-D \\
\hline Scientific Name & $\begin{array}{c}\text { ChAdOx1 } \\
\text { nCoV-19 } \\
\text { Corona Virus } \\
\text { vaccine } \\
\text { Recombinant) } \\
\text { [Chimpanzee } \\
\text { Adeno vector] }\end{array}$ & $\begin{array}{l}\text { Whole-Virion } \\
\text { Inactivated } \\
\text { SARS CoV-2 } \\
\text { Vaccine }\end{array}$ & $\begin{array}{c}\text { Recombinant } \\
\text { Adenovirus } \\
\text { vector based } \\
\text { SARS-CoV-2 } \\
\text { liquid vaccine } \\
\text { Gam COVID } \\
\text { Vac }\end{array}$ & $\begin{array}{c}\text { mRNA- } \\
\text { 1273COVID- } \\
19 \text { vaccine }\end{array}$ & $\begin{array}{c}\text { COVID-19 } \\
\text { vaccine } \\
\text { (Ad26.COV2- } \\
\text { S) } \\
\text { [recombinant] }\end{array}$ & $\begin{array}{c}\text { Novel Corona } \\
\text { Virus-2019- } \\
\text { nCov vaccine } \\
\text { (recombinant } \\
\text { DNA) }\end{array}$ \\
\hline $\begin{array}{l}\text { Component of } \\
\text { Viral vector }\end{array}$ & $\begin{array}{l}\text { Non-Replicated } \\
\text { Viral Vector }\end{array}$ & $\begin{array}{l}\text { Whole Virus- } \\
\text { Inactivated }\end{array}$ & $\begin{array}{c}\text { Non- } \\
\text { Replicated } \\
\text { Viral Vector }\end{array}$ & $\begin{array}{l}\text { RNA- Based } \\
\text { Viral Vector }\end{array}$ & $\begin{array}{l}\text { Non-Replicated } \\
\text { Viral Vector }\end{array}$ & $\begin{array}{l}\text { DNA- Based } \\
\text { Viral Vector }\end{array}$ \\
\hline $\begin{array}{c}\text { Dosing } \\
\text { Schedule }\end{array}$ & $\begin{array}{c}\text { Two doses, } 4 \text { to } \\
6 \text { weeks } \\
\text { apart }\end{array}$ & $\begin{array}{l}\text { Two doses, } \\
\text { Day } 0 \& 28\end{array}$ & $\begin{array}{c}\text { Two doses, } \\
\text { Day } 0 \text { \& Day } \\
21\end{array}$ & $\begin{array}{l}\text { Two doses, } \\
\text { Day } 0 \& 28\end{array}$ & Single dose & $\begin{array}{c}\text { Three doses } \\
\text { (Day 0, 28 } \\
\text { and 56) }\end{array}$ \\
\hline Age Group & $\begin{array}{c}\text { For } \geq 18 \text { years } \\
\text { age }\end{array}$ & $\begin{array}{c}\text { For } \geq 18 \text { years } \\
\text { age }\end{array}$ & $\begin{array}{c}\text { For } \geq 18 \text { years } \\
\text { age }\end{array}$ & $\begin{array}{c}\text { For } \geq 18 \text { years } \\
\text { age }\end{array}$ & $\begin{array}{c}\text { For } \geq 18 \text { years } \\
\text { age }\end{array}$ & $\begin{array}{l}\text { For } \geq 12 \\
\text { years age }\end{array}$ \\
\hline $\begin{array}{c}\text { Route of } \\
\text { administration }\end{array}$ & Intramuscular & Intramuscular & Intramuscular & Intramuscular & Intramuscular & Intradermal \\
\hline Storage & $2-8^{\circ} \mathrm{C}$ & $2-8^{\circ} \mathrm{C}$ & $-18^{\circ} \mathrm{C}$ & $\begin{array}{c}-25^{\circ} \mathrm{C} \text { to } \\
15^{\circ} \mathrm{C}\end{array}$ & $\begin{array}{c}-25^{\circ} \mathrm{C} \text { to }-15^{\circ} \mathrm{C} \\
\& 2-8^{\circ} \mathrm{C}\end{array}$ & $2-8^{\circ} \mathrm{C}$ \\
\hline $\begin{array}{l}\text { Firm and date } \\
\text { of approval }\end{array}$ & $\begin{array}{c}\text { M/s Serum } \\
\text { Institute of India } \\
\text { Pvt. Ltd. } \\
\text { 03.01.2021 }\end{array}$ & $\begin{array}{l}\text { M/s Bharat } \\
\text { Biotech } \\
03.01 .2021\end{array}$ & $\begin{array}{c}\text { M/s Dr. } \\
\text { Reddy's Lab. } \\
\text { Ltd. } \\
\text { (Importer) } \\
\text { 12.04.2021 \& } \\
\text { M/s Panacea } \\
\text { Biotech Ltd } \\
\text { 02.07.2021 }\end{array}$ & $\begin{array}{c}\text { M/s Cipla } \\
\text { Ltd. } \\
\text { (Importer) } \\
29.06 .2021\end{array}$ & $\begin{array}{l}\text { M/s Johnson \& } \\
\text { Johnson Pvt. } \\
\text { Ltd. (Importer) } \\
\text { 07.08.2021 \& } \\
\text { Biological E } \\
\text { Limited } \\
\text { 18.08.2021 }\end{array}$ & $\begin{array}{l}\text { Cadila } \\
\text { Healthcare } \\
\text { Limited } \\
20.08 .2021\end{array}$ \\
\hline
\end{tabular}




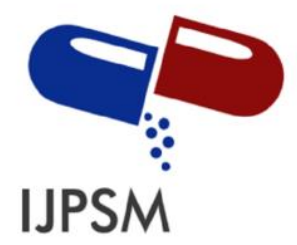

R. Vinoth et al, Int. Journal of Pharmaceutical Sciences and Medicine (IJPSM), Vol.6 Issue. 10, October- 2021, pg. 16-25

ISSN: 2519-9889

Impact Factor: 3.426

\section{Conclusion}

COVID 19 disease was treated with vaccines and drugs, and the study's findings were presented. Several diagnostic approaches were investigated due of the test's accessibility. Patients were given drugs based on the severity of their symptoms during anaphylactic treatment. Vaccination (prophylactic treatment) has been used as a preventive therapy to prevent and control the spread of disease all over the world, and India has published its complete list of licenced vaccine candidates till September 2021. As a result, this study will be incredibly useful in terms of learning more about COVID 19 therapy. To assist the COVID 19 research teams in identifying future drugs that are both effective and affordable.

\section{Conflict of Interest:}

Authors do not have any conflict of interest with each other

\section{References}

[1] World Health Organization. Coronavirus 2021; Accessed at: https://www.who.int/healthtopics/coronavirus

[2] Chan JF, Lau SK, To KK, Cheng VC, Woo PC, Yuen KY. Middle East respiratory syndrome coronavirus: another zoonotic beta coronavirus causing SARS-like disease. Clinical microbiology reviews. 2015 Apr 1;28(2):465-522.

[3] Public Health England. COVID-19: epidemiology, virology and clinical features. Accessed at https://www.gov.uk/government/publications/wuhan-novel-coronavirus-backgroundinformation/wuhan-novel-coronavirus-epidemiology-virology-and-clinical-features.

[4] McIntosh K, Becker WB, Chanock RM. Growth in suckling-mouse brain of "IBV-like" viruses from patients with upper respiratory tract disease. Proc Natl Acad Sci USA 1967; 58: 2268-2273.

[5] Tyrrell DA, Almeida JD, Cunningham CH, Coronaviridae. Intervirology 1975; 5: 76-82.

[6] Bradburne AF. Antigenic relationships amongst coronaviruses. Archiv Gesamte Virusforsch 1970; $31: 352$ 364.

[7] McIntosh K, Kapikia AZ, Hardison KA, Antigenic relationships among the coronaviruses of man and between human and animal coronaviruses. Journal of Immunology 1969; 102: 1109-1118.

[8] McIntoshK, Chao RK, Krause HE, Wasil R, Mocega HE. Coronavirus infection in acute lower respiratory tract disease of infants. Journal of Infectious Disease 1974; 130: 502-507.

[9] Wenzel RP, Hendley JO, Davies JA, Coronavirus infections in military recruits. Three-year study with coronavirus strains OC43 and 229E. American Review of Respiratory Disease 1974; 109: 621-624.

[10] Moses R. COVID-19: Respiratory Physiotherapy on Call Information and Guidance. Lancashire Teaching Hospitals 2020; 01-12.

[11] World Health Organisation. Clinical management of severe acute respiratory infection when novel coronavirus (2019-nCoV) infection is suspected. January 2020. Accessed at https://www.who.int/docs/default-source/coronaviruse/clinical-management-of-novel-cov.pdf

[12] Government of India Ministry of Health and Family Welfare; Version 6, 24.05.21. Accessed at https://www.mohfw.gov.in/pdf/UpdatedDetailedClinicalManagementProtocolforCOVID19adultsdated2405 2021.pdf

[13] Cascella M, Rajnik M, Cuomo A, et al., Features, evaluation and treatment coronavirus (COVID-19). Stat pearls [internet]. Treasure Island (FL): Stat Pearls Publishing, Jan 2020; 12-24.

[14] Yang AP, Liu JP, Tao WQ, et al. The diagnostic and predictive role of NLR, d-NLR and PLR in COVID-19 patients. Int Immunopharmacol 2020; 84:106504.

[15] Fang Y, Zhang H, Xie J, et al. Sensitivity of chest CT for COVID-19: comparison to RT-PCR. Radiology 2020, Accessed at https://pubmed.ncbi.nlm.nih.gov/32073353/

[16] Government of India Ministry of Health and Family Welfare; Version 6, 24.05.21. Accessed at https://www.mohfw.gov.in/pdf/UpdatedDetailedClinicalManagementProtocolforCOVID19adultsdated2405 2021.pdf

[17] Mehra, M.R., Desai, S.S., Ruschitzka, F., Patel, A.N., 2020. RETRACTED: hydroxychloroquine or chloroquine with or without a macrolide for treatment of COVID-19: a multinational registry analysis. Lancet S0140-6736 (20), 31180-31186. 


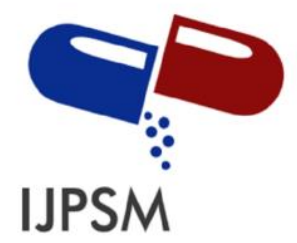

\section{R. Vinoth et al, Int. Journal of Pharmaceutical Sciences and Medicine (IJPSM), Vol.6 Issue. 10, October- 2021, pg. 16-25}

ISSN: 2519-9889

Impact Factor: 3.426

[18] Colson P, Rolain JM, Raoult D. Chloroquine for the 2019 novel coronavirus SARS-CoV-2. International journal of antimicrobial agents 2020; 55:105923.

[19] Cortegiani A, Ingoglia G, Ippolito M, Giarratano A, Einav S. A systematic review on the efficacy and safety of chloroquine for the treatment of COVID-19. Journal of critical care 2020. 59:176-190.

[20] Tang W, Cao Z, Han M, Wang Z, Chen J, Sun W, et al. Hydroxychloroquine in patients with mainly mild to moderate coronavirus disease 2019: open label, randomised controlled trial. BMJ. 2020, Accessed at https://www.bmj.com/content/369/bmj.m1849/rapid-responses.

[21] Vastag B. Old drugs for a new bug: influenza, HIV drugs enlisted to fight SARS. Jama 2003; 290:16951696.

[22] Cao B, Wang Y, Wen D, Liu W, Wang J, Fan G, et al. A trial of lopinavir-ritonavir in adults Hospitalized with Severe Covid-19. The New England journal of medicine 2020; 382:1787-1799.

[23] Vastag B. Old drugs for a new bug: influenza, HIV drugs enlisted to fight SARS. Jama 2003; 290:16951696.

[24] Cao B, Wang Y, Wen D, Liu W, Wang J, Fan G, et al. A trial of lopinavir-ritonavir in adults Hospitalized with Severe Covid-19. The New England journal of medicine 2020; 382:1787-1799.

[25] Choy KT, Wong AY, Kaewpreedee P, Sia SF, Chen D, Hui KPY, et al. Remdesivir, lopinavir, emetine, and homoharringtonine inhibit SARS-CoV-2 replication in vitro. Antiviral Res. 2020; 178:104786.

[26] Wang M, Cao R, Zhang L, Yang X, Liu J, Xu M, et al. Remdesivir and chloroquine effectively inhibit the recently emerged novel coronavirus (2019-nCoV) in vitro. Cell research 2020; 30:269-271.

[27] Veklury (remdesivir) injection package insert. Foster City, CA: Gilead Sciences, Inc; 2020 Oct.

[28] U.S. Food and Drug Administration. FDA communication on remdesivir Emergency Use Authorization; 2020. Accessed at https://www.fda.gov/media/137564/download

[29] Food and Drug Administration (FDA). Fact sheet for health care providers: emergency use authorization (EUA) of Veklury (remdesivir) for hospitalized pediatric patients weighing $3.5 \mathrm{~kg}$ to less than $40 \mathrm{~kg}$ or hospitalized pediatric patients less than 12 years of age weighing at least $3.5 \mathrm{~kg}$. Retrieved October 23 , 2020. Accessed at https://www.fda.gov/media/137566/download

[30] Food and Drug Administration (FDA). Fact sheet for health care providers emergency use authorization (EUA) of remdesivir (GS-5734). Retrieved; 2020. Accessed at: https://www.fda.gov/media/137566/download

[31] Gilead Sciences, Inc. Gilead announces approval of Veklury (remdesivir) in Japan for patients with severe COVID-10. Retrieved July 8, 2020. Accessed at: https://www.gilead.com/news-and-press/press-room/pressreleases/2020/5/gilead-announces-approval-of-veklury-remdesivir-in-japan-for-patients-with-severe-covid19

[32] Gilead Sciences, Inc. European commission grants conditional marketing authorization for Gilead's Veklury (remdesivir) for treatment of COVID-19. Retrieved; 2020. Accessed at: https://www.gilead.com/news-andpress/press-room/press-releases/2020/7/european-commission-grants-conditional-marketing-authorizationfor-gileads-veklury-remdesivir-for-the-treatment-of-covid19

[33] Kroot, E.J.A.; Huisman, A.M.; Zeben, J.V.; Wounters, J.M.G.W.; Paassen, H.C.V. Oral Pulsed Dexamethasone Therapy in Early Rheumatoid Arthritis. Ann. N. Y. Academic Sciences 2006, 1069, 300306.

[34] Gogali, A.; Kyriakopoulos, C.; Kostikas, K. Corticosteroids in Covid-19: One size does not fit all. European Respiratory Journal 2021, 57, 210-224.

[35] Halpin, D.M.G.; Singh, D.; Harfield, R.M. Inhaled corticosteroids and COVID-19: A systematic review and clinical perspective. European Respiratory Journal 2020, 57, 20(1) 12-19.

[36] Hall, B.M.; Head, H.; Neurology, H.O. Corticosteroids in autoimmune diseases. Australian Prescribers Journal 1999, 22, 9-11.

[37] Liu, J.; Zheng, X.; Huang, Y.; Shan, H.; Huang, J. Successful use of methylprednisolone for treating severe COVID-19. J. Allergy Clinical Immunology 2020, 146, 325-327.

[38] Gopalaswamy, R.; Subbian, S. Corticosteroids for COVID-19 Therapy: Potential Implications on Tuberculosis. International Journal of Molecular Sciences 2021, 22, 3773.

[39] Beigel JH, Tomashek KM, Dodd LE, et al. Remdesivir for the treatment of Covid-19 preliminary report. New England Journal of Medicine 2020 Accessed at https://www.nejm.org/doi/full/10.1056/NEJMc2022236

[40] Casirivimab injection, solution, concentrate Imdevimab injection, solution, concentrate REGEN-COVcasirivimab and imdevimab kit". Daily Med. Retrieved 2021, Accessed at 


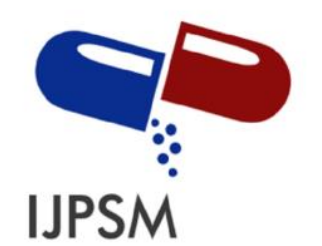

R. Vinoth et al, Int. Journal of Pharmaceutical Sciences and Medicine (IJPSM),

Vol.6 Issue. 10, October- 2021, pg. 16-25

ISSN: 2519-9889

Impact Factor: 3.426

https://dailymed.nlm.nih.gov/dailymed/drugInfo.cfm?setid=f5bf7a31-7e17-4a94-805c-

d231ea458fb0\&audience=consumer

[41] Fact Sheet for Health Care Providers Emergency Use Authorization (EUA) Of Casirivimab and Imdevimab. U.S. Food and Drug Administration (FDA) 2021, Accessed at https://www.fda.gov/emergencypreparedness-and-response/mcm-legal-regulatory-and-policy-framework/emergency-use-authorization

[42] Sanders, J. M., Monogue, M. L., Jodlowski, T. Z., and Cutrell, J. B. (2020). Pharmacologic Treatments for coronavirus disease 2019 (COVID-19): a review. JAMA. 323, 1824-1836.

[43] Wang, M., Cao, R., Zhang, L., Yang, X., Liu, J., Xu, M., et al. (2020). Remdesivir and chloroquine effectively inhibit the recently emerged novel coronavirus (2019-nCoV) in vitro Cellular Research 30, 269271.

[44] Vignesh, R., Shankar, E. M., Vijayakumar, V. \& Thyagarajan, S. P. Is Herd Immunity against SAR-CoV2 a silver lining? Frontiers in Immunology; 11, 586781; 2020, Accesses at https://www.frontiersin.org/articles/10.3389/fimmu.2020.586781/full

[45] Vaccine Candidates Approval in India, Accessed at https://covid19.trackvaccines.org/

[46] Central Drugs Standard Control Organization 2021; Accessed at http://cdsco.gov.in. 